\title{
Chronology
}

1368-I372 Emperor Hongwu holds a grand Dharma assembly at Jiangshansi 蔣 山寺 in Nanjing each of the five years

I38I Establishment of the Central Buddhist Registry (僧錄司) in place of the Bureau of Buddhist Patriarchs (善世院), with the rank of its heads lowered significantly.

I384 Establishment of ordination system for Buddhist monks and nuns

1391 Reclassification of Buddhism into Chan 禪, jiang 講 (doctrinal schools), and jiao 教 (esoteric Buddhism), with different policies applied to each

Amalgamation of Buddhist temples

I394 Prohibition of monks from associating with officials and from traveling for donations and collections

Enforcement of the Zhouzhice 周知册, which first appeared in 1372 Enshrinement of the Huang Ming zuxun 皇明祖訓

I417 Building of new temples prohibited

I4I8 Restrictions on monks both in number and in qualifications

I45I Sale of ordination certificate for the first time in the Ming

I52I Emperor Jiajing unexpectedly ascends the throne from the rank of local prince, soon sparking the Great Rites Controversy

I527 Jiajing fails in an attempt to close Baomingsi 保明寺

Fang Xianfu 方獻夫 reportedly destroys six hundred nunneries in Beijing

I529 Wang Yangming 王陽明 dies

I530 Removal of Yao Guangxiao's 姚廣孝 spirit tablet from the imperial temple 
Huo Tao 霍䤾 destroys about one hundred and forty nunneries in Nanjing and forces about five hundred nuns to return to secular life

Shixingsi 實性寺 in Shaoxing 紹興 is destroyed

I54I Jiajing survives an attempted assassination

I550

Eunuchs rebuild Jietansi 戒壇寺 in Beijing, with a Daoist statue included in it

Eunuchs gradually turn Huguosi 護國寺 into their ancestral temple Puhuisi 普惠寺 in Jiaxing 嘉興 is destroyed

Xilin Yongning 西林永寧 dies; Hanshan Deqing 懸山德清 is tasked with saving the dilapidated Great Baoen monastery

The ordination platforms in Beijing and Hangzhou are closed and not reopened until fifty years later

Miaofeng Fudeng 妙峰福登 visits Putuo Island and later meets Deqing in Nanjing

Deqing arrives in Beijing, where he meets Fudeng again. The following year they go to Mount Wutai and live there for the following ten years

I573 Emperor Wanli ascends the throne at the age of ten. In the following decade, the court is controlled by senior Grand Secretary Zhang Juzheng 張居正, Empress Dowager Cisheng 慈聖, and the eunuch Feng Bao 馮保

Cisheng and eunuchs come to patronize Puansi 普安寺

Feng Bao renovates Huguosi

I573 I582 With major support from the inner court, leading monasteries in Beijing are (re)built and allegedly become more magnificent than those in Nanjing

1574

Shixingsi is restored

I576

Puhuisi is restored by Lu Guangzu 陸光祖

I58I-I582 A Dharma assembly is held at Mount Wutai, leaving a profound impact on Deqing's life and career

I582 Zhang Juzheng dies; Zhu Changluo 朱常洛 is born; Feng Bao is exiled

Deqing visits Beijing from Shanxi and lives nearby in search of support from the inner court

I583 Zhang Juzheng's house is confiscated

Deqing is forced to head for Mount Lao 嶗山 in Shandong

I584 Fudeng visits Beijing in response to Cisheng's call, while Deqing declines, isolating himself from the world

Mizang Daokai 密藏道開 and Zibo Zhenke 紫柏真可 set up contact with Cisheng through eunuchs 
I585 Li Zhi 李䞇 shaves off his hair and resigns from office. Yuan Hongdao 袁宏道 visits Li several times in the following few years

I586 Lady Zheng 鄭 gives birth to Zhu Changxun 朱常洵, Wanli's third son, which starts the succession issue at Wanli court

1586-1587 Cisheng bestows fifteen sets of the Buddhist canon, which encourages Deqing as their recipient to leave his isolation at Mount Lao

1587 Feng Mengzhen 馮夢楨 retreats to Hangzhou after being demoted from the post of Hanlin bachelor in Beijing and starts a close connection with Zhenke and Daokai

I589 Cisheng distributes more than twenty sets of the Buddhist canon for the benefit of Zhu Changluo, Wanli's first son and the future crown prince

Lady Zheng dispatches eunuchs to Mount Tai requiring the abbot of Sanyang abbey 三陽觀 to pray for Zhu Changxun

Deqing returns to the Great Baoen monastery; Cisheng agrees to help restore the monastery

Zhenke and Daokai initiate the huge project of carving the Jiaxing canon

I590 Wanli claims that the crown prince will be officially established in two years

Deqing is sued by the Daoist Geng Yilan 耿義蘭 for robbing the grounds of a Daoist abbey to construct Haiyinsi 海印寺, but he easily wins the case

I590-I592 Lady Zheng prays in the Daoist Dongyue temple 東獄廟 in Beijing on behalf of her son Zhu Changxun, hinting in public that he is the crown prince

Around 1590, patrons of Dongyue temple soar in number

1592 Wanli breaks the promise to announce the crown prince, and the succession issue continues

The anxious Empress Wang 王 carves the Guanyin lingke 觀音靈課

Deqing meets Zhenke in Beijing and is reminded of emerging dangers

Tanzhesi 潭柘寺 is renovated and expanded on a large scale under the charge of the eunuch Xu Zhengguang 徐正光, whom Cisheng trusts

1592-I594 Deqing frequently visits Beijing and prays at Cishousi 慈壽寺 for the sake of Zhu Changluo

I594 Lady Zheng dispatches eunuchs to Sanyang abbey on Mount Tai to pray for Zhu Changxun, who is called taizi 太子 (crown prince) again 
Deqing is exiled to Guangdong; the eunuch Zhang Ben 張本 is sentenced to death

Wanli is absent from the ceremony celebrating Cisheng's birthday

Yuan Hongdao takes up the post of magistrate of Suzhou

1596

1597

1598

I598-I600

I598-1605

1600

I60I

1603 $1603-1604$

1606

1608

I6IO

I6II

1612

1602

Lady Zheng prays in Sanyang abbey again for her son

Yuan Hongdao resigns his office but takes up another post in Beijing the next year

The first “evil pamphlet” (yaoshu 妖書) event breaks out

The Putao Association 葡萄社 is convened; Yuan Hongdao composes the Xifang helun 西方合論 sometime later

Wanli bestows the Buddhist (and Daoist) canon on a large scale

Yuan Hongdao changes his outlook substantially after witnessing a series of deaths

Wanli shows favor to the Daoist Geng Yilan, who had charged Deqing without basis

Zhu Changluo is established as the crown prince but threats to him persist

Zhenke visits Beijing; eunuchs rush out to welcome him, but his disciples and friends all warn him of imminent danger

The Putao Association disbands; its major members include several of Zhu Changluo's tutors

Li Zhi dies in prison

Wanli recovers from an acute illness, which becomes the chance for him to improve his relationship with his mother

The second evil pamphlet event takes place

Zhenke dies behind bars. Wuqiong Zhenfa 無穿真法, from Mount Emei, dies mysteriously, and Wuyan Zhengdao 無言正道, from Shaolinsi 少林寺, is thrown into prison. Jieshan Furu 戒山傅如 is arrested and taken to Beijing from Hangzhou

Around this year, the so-called Donglin faction 東林黨 arises

Yuan Hongdao returns to Beijing; he is disappointed with the state of Buddhism there but fulfills his official responsibility effectively

Feng Mengzhen dies

Pumen Weian 普門惟安 visits Beijing to elicit support for Ciguangsi 慈光寺

Yuan Hongdao dies

Factionalism at the Wanli court intensifies

Fudeng dies. Ciguangsi receives imperial favor from both Cisheng and Wanli 
I6I 4 Cisheng dies; Ye Xianggao 葉向高 resigns his office

I6I5 Yunqi Zhuhong 雲棲袾宏 dies

I617 Zhencheng dies

$1620 \quad$ Wanli dies; Zhu Changluo dies

1623 Deqing dies

1625 Weian dies

1666-1670 Ciguangsi is finally expanded with support from local merchants I680s The revival of Chan Buddhism ceases, and the gentry's patronage of Buddhism declines

1699 The Great Baoen monastery is rebuilt with government money Chongfusi 崇福寺 and Tanzhesi both thrive with royal patronage during the early Qing 



\section{Thriving in Crisis}


